Studies of the genetic and phenotypic correlations between different information from the lactation showed that the last test was the single information with the highest correlations with the unknown part of the lactation.

Five different extention equations were compared : three ratio and two regression equations. The ratio equations were : I) a ratio extention of part-lactation to total lactation directly and 2) two ratio equations to estimate the rest-lactation from the last test. The regression equations were a linear regression of the rest-lacation on the last test and a multiple regression of partlactation, last-test and test before last test on total total lactation.

The last method was found to be the best in terms of the precision of the extention, but the three methods using last test to estimate rest-lactation were very close to the multiple regression.

It is concluded, with reference to the applicability, that the ratio equations to estimate the rest-lactation from the last test should be prefered in practice.

\title{
RELATIONSHIPS BETWEEN THE RESISTANCE TO MASTITITS AND SOME UDDER AND MILKING CHARACTERISTICS
}

\section{J. Philipsson, A. M. Luxdeekg. --. Department of Animal Breeding, Agricultural College, S-i.50 Or UPPSA L.A 7. Sweden.}

The relationships between the resistance to mastitis, measured by the CMT, on the one hand and ease of milking and various characteristics of udder and teats, on the other, were studied on 8 farms with Swedish Red and White (SRB) cows and 9 farms with Swedish Friesian $(S L B)$ cows.

The correlations between rate of mastitis and ease of milking were very low and generally non-significant. The relationships with the proportion of the milk from the fore udder were significant in most cases. Large proportions are correlated to higher rates of mastitis in the hind quarters and small proportions to higher rates of mastitis in the fore quarters. Significant correlations were also found with udder height, while other relationships were weaker.

\section{EVIDENCE FOR A POSSIBLE INFLUENCE OF THE FETUS IN THE MILK YIELD OF THE DAM}

\section{H. SkJervold, E. Fimland. - Institute of Animal Genetic and Breeding, Agricultural University of Norway, $\AA_{s-N L H, \text { Nonway. }}$}

It has been observed from the literature that hormone activity of the fetal placenta stimulate mammary developements during the pregnancy. The milk production is also indicated to be limited by the number of milk-synthesizing cells. Observing these two findings together may suggest a working hypothesis that the genotype of the fetus affects the milk production of the clam.

In order to test this hypothesis, first lactation cows calved in the fall were used. Altogether four production years were analysed. The data contained $t^{8} 852$ lactations and 1247 sires of the calves. The characters considered were lactation yield and maximum daily yield. The lactation yield was corrected for age and expressed as deviation from the herd-average .The maximum daily yield was corrected for the herd-average by using linear regression.

The components of variance were obtained by nested half-sib analysis. The components of variance of the sire of the calves were estimated by nesting the sires of the cows within the sires of the calves.

The fetal sire effect on the milk production of the dam was expressed as the coefficient of correlation between the phenotype of milk production of the dam and the genotype of the sire of the calf. The estimates of these correlations range from 0.08 to 0.13 for lactation yield and from 0.07 to 0.09 for maximum daily yield. These coefficients were all significantly different from zero.

The genetic correlation estimated between the proof of the sire of the dam and the proof of the same bull as calf sire was essentially zero and non-significant. 